\title{
First abundance estimate for white whales Delphinapterus leucas in Svalbard, Norway
}

\author{
Jade Vacquié-Garcia ${ }^{1}$, Christian Lydersen ${ }^{1}$, Tiago A. Marques ${ }^{2,3}$, \\ Magnus Andersen ${ }^{1}$, Kit M. Kovacs ${ }^{1, *}$ \\ ${ }^{1}$ Norwegian Polar Institute, Fram Centre, 9296 Tromsø, Norway \\ ${ }^{2}$ Centre for Research into Ecological \& Environmental Modelling (Scottish Oceans Institute), Buchanan Gardens, St Andrews, \\ KY16 9LY, UK \\ ${ }^{3}$ Departamento de Biologia Animal, Centro de Estatística e Aplicações da Universidade de Lisboa, Campo Grande, \\ 1749-016 Lisboa, Portugal
}

\begin{abstract}
The Svalbard Archipelago (Norway) is experiencing rapid declines in the seasonal duration and extent of sea-ice cover, and local tidewater glaciers are melting. These environmental changes represent a threat to ice-associated species in the region, including white whales Delphinapterus leucas. However, no estimates of stock size or trends are available for this stock. An aerial survey was conducted during the summer of 2018, covering the coastlines of all major islands in Svalbard, as well fjords and open ocean areas. A total count was attempted for the coastlines, while coverage of the fjords and open ocean areas was designed as distance-sampling line transects. In total, 265 white whales were detected in 22 groups along the $4965 \mathrm{~km}$ of coastline coverage. No whales were observed on fjord $(1481 \mathrm{~km})$ or open ocean transects $(535 \mathrm{~km})$. After correcting for surface availability using behavioural data from the same area (in summer) and making adjustments for small areas not flown during the survey, the stock size was estimated to be 549 individuals (95\% CI: 436-723). This estimate is surprisingly low given that this species is one of the most frequently observed cetaceans in the area, but it confirms suspicions based on difficulties in finding animals when operating white whale tagging programmes over the past decade. This first population estimate is important in the context of the rapid environmental change taking place in the Arctic and for providing a baseline for comparison with future estimates.
\end{abstract}

KEY WORDS: Beluga $\cdot$ Arctic $\cdot$ Baseline population estimate $\cdot$ Climate change $\cdot$ Environmental change $\cdot$ Space use $\cdot$ Adaptation $\cdot$ Prey shifting

\section{INTRODUCTION}

The Arctic has experienced a rapid reduction in sea ice over the last few decades, and in some areas tidewater glaciers are retracting onto land (Stroeve et al. 2007, Lydersen et al. 2014). Such changes represent direct loss of habitat for ice-associated marine mammals, which use these environments for breeding and foraging (Stirling 1997, Heide-Jørgensen \& Laidre 2004, Lydersen et al. 2014). Ice-covered areas also provide Arctic endemic marine mammals shelter from open-water predators, many potential human

${ }^{*}$ Corresponding author: kit.kovacs@npolar.no impacts and inclement weather. Thus, reduction of these habitats is a serious threat to this group of mammals.

The white whale Delphinapterus leucas is an Arctic endemic marine mammal that is widely distributed throughout Arctic waters. Globally, there are thought to be around 200000 individuals, divided among about 20 recognized stocks (Lowry et al. 2017). The Western Hudson Bay, Beaufort Sea, Baffin Bay and Chuckchi stocks are the 4 largest, each numbering more than 20000 individuals (Innes et al. 2002, Muto et al. 2016, Lowry et al. 2017, Matthews

(C) The authors 2020. Open Access under Creative Commons by Attribution Licence. Use, distribution and reproduction are unrestricted. Authors and original publication must be credited. 
et al. 2017), while the Ungava and Cook Inlet stocks are the smallest, with less than 500 individuals each (Doniol-Valcroze \& Hammill 2012, Shelden et al. 2015).

At the species level, white whales are listed on the IUCN Red List as 'Least Concern'; however, several white whale stocks are listed as Endangered or Critically Endangered, while others are Data Deficient because they have never been estimated (Lowry et al. 2017). One of the unknown stocks resides in the Svalbard Archipelago in the Norwegian High Arctic. This region has been strongly affected by climate change, experiencing the greatest decrease in the seasonal duration of sea-ice cover within the circumpolar Arctic (Laidre et al. 2015). Most glaciers in the area are in a state of negative mass balance (Moholdt et al. 2010, Nuth et al. 2010, Lydersen et al. 2014, Torsvik et al. 2019). The white whale stock in this region is genetically differentiated from the West Greenland stock to the west (O'Corry-Crowe et al. 2010); its genetic relationship with white whales in Frans Josef Land to the east is currently unknown (Lønø \& Øynes 1961, O'Corry-Crowe et al. 2010), although tracking data from Svalbard do not suggest routine movements between these archipelagos in recent decades (Lydersen et al. 2001, Vacquié-Garcia et al. 2018).

White whales in Svalbard were harvested, first by Russian whalers/trappers and then by Norwegians (Lønø \& Øynes 1961), who in combination killed more than 15000 animals from the $18^{\text {th }}$ century to the early 1960s (Lønø \& Øynes 1961, Gjertz \& Wiig 1994). Since the 1960s, when the whales were described as being severely depleted and 'commercially extinct', the stock has been totally protected in Svalbard (Gjertz \& Wiig 1994). Despite the large number of animals caught in the past, white whales are one of the most commonly observed cetaceans in this area (Storrie et al. 2018). In recent years, the habitat use of white whales in Svalbard waters has been investigated using satellite tracking, which has revealed that they are year-round residents and occupy areas close to the coast (Lydersen et al. 2001, Vacquié-Garcia et al. 2018). A seasonal movement pattern occurs, with animals generally spending more time on the west coast of Spitsbergen in summer and then moving southward and eastward to the east coast as winter approaches (Lydersen et al. 2001, Vacquié-Garcia et al. 2018). During ice-free periods of the year, the white whales in Svalbard spend most of their time close to the fronts of tidewater glaciers (Lydersen et al. 2001, Vacquié-Garcia et al. 2018), similar to many other Arctic species (Lydersen et al. 2014), likely foraging on polar cod Boreogadus saida (Dahl et al.
2000) which congregate in the cold water areas in front of glaciers. When they move from one glacier front to another, they do so in an extremely coastal manner, probably to minimize distance travelled and perhaps also to avoid predation (Lydersen et al. 2001, Vacquié-Garcia et al. 2018). When the sea ice forms in winter, animals on the east side of Svalbard are pushed offshore, where they occupy areas with drifting sea ice, sometimes with more than $90 \%$ ice cover, but they still generally stay in waters close to the Svalbard Archipelago (Lydersen et al. 2001, 2002, Vacquié-Garcia et al. 2018). Recent tracking studies of white whales in Svalbard (2013-2016) have shown that, compared to previous decades, they now spend somewhat more time away from the glacier fronts, out in the fjords (Vacquié-Garcia et al. 2018, Hamilton et al. 2019). This might be a response to increased influxes of Atlantic Water, with associated prey organisms in the fjords along the west coast of Svalbard (e.g. Cottier et al. 2007, Spielhagen et al. 2011, Berge et al. 2015).

The objective of this study was to conduct the first aerial survey for white whales within the Svalbard Archipelago to provide a robust abundance estimate for this currently unknown stock. Tracking studies were used to (1) design the survey such that all habitats used by the whales would receive appropriate coverage and (2) calculate correction factors for availability at the surface.

\section{MATERIALS AND METHODS}

\subsection{Design and execution of the aerial survey}

The survey was flown in July and August 2018 using a Vulcanair P68 Observer 2 fixed wing aircraft, with a plexi-glass front (optimizing forward visibility) and bubble windows on both sides in the back (optimizing lateral visibility to the sides of the aircraft). Flights were conducted at an altitude of $\sim 1000 \mathrm{ft}$ $(305 \mathrm{~m})$ and at a speed of $\sim 100$ knots $\left(185 \mathrm{~km} \mathrm{~h}^{-1}\right)$. During the survey, 4 observers (including the pilot) acted as a single observation team. The 2 observers in the front seats focussed on detections on or close to the transect line in front of the aircraft, while the 2 observers in the back focussed on their respective sides of the aircraft further away from the transect line, but with some overlap with the front observers' search areas.

Tracking data from July and August 2013-2016 ( $N=16$, Fig. 1; Vacquié-Garcia et al. 2018) were used to build the design of the survey, providing distribu- 


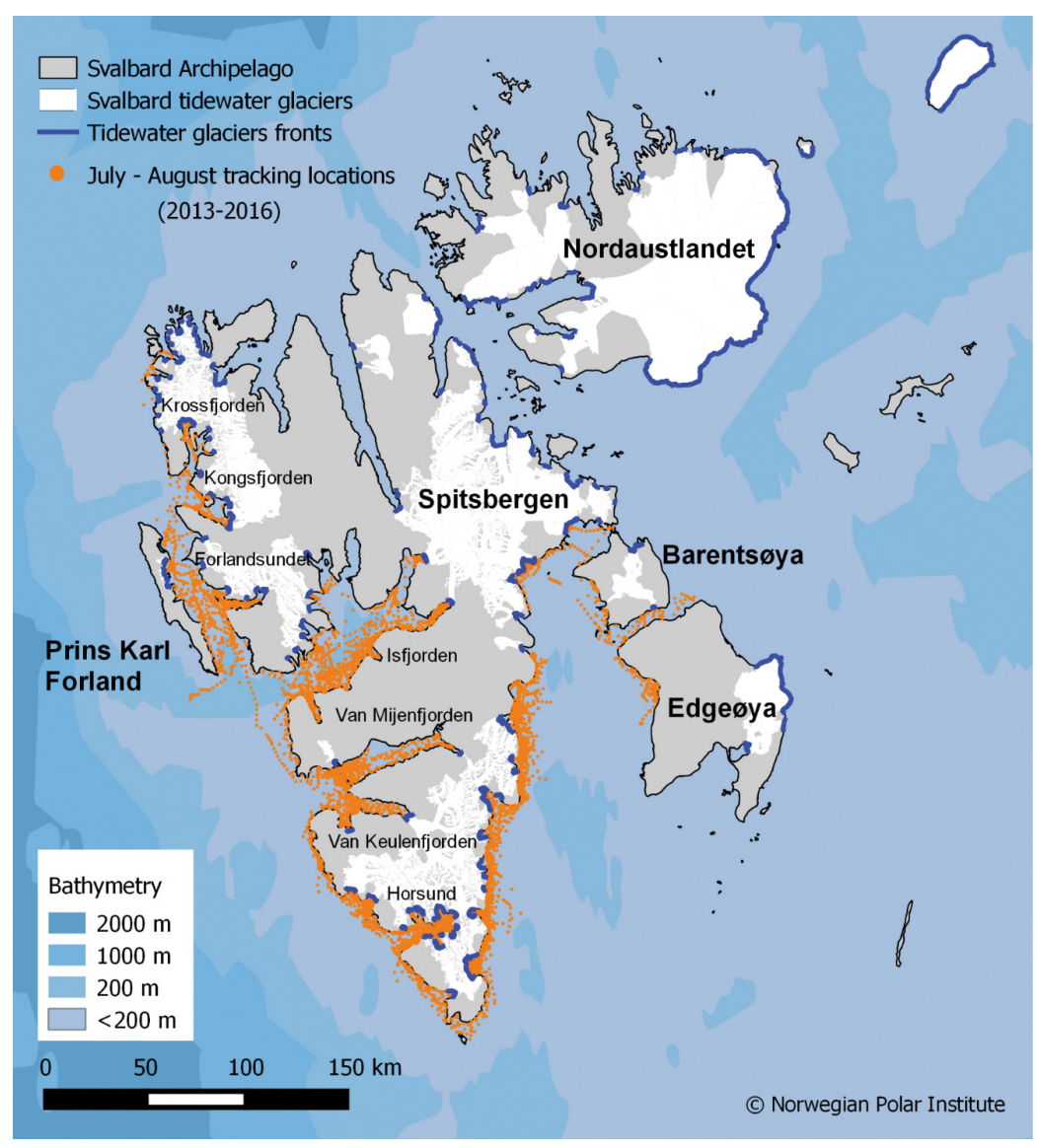

Fig. 1. Summer tracking data for male white whales in the Svalbard Archipelago, Norway, used to create the survey design $(\mathrm{N}=16$; for more details see Vacquié-Garcia et al. 2018)

tion information for the period of the survey from earlier years and integrating a recent change in behaviour of male white whales. Three different strata, COAST, FJORD and OPEN OCEAN, were identified within a band of $12.4 \mathrm{~km}$ from the shore, which encompassed virtually all (99.6\%) of the white whale locations documented in the tracking data (Figs. 1 \& 2; Vacquié-Garcia et al. 2018).

A total count was attempted for the COAST stratum, which included Svalbard coastlines and all tidewater glacier fronts occurring on Spitsbergen, Edgeøya, Barentsøya, Prins Karls Forland and Nordauslandet, as well as coastlines of most of the smaller islands in the archipelago (Figs. $1 \& 2$ ). This was carried out by flying along the coastlines at a distance of $400 \mathrm{~m}$ from shore (Fig. 2A). This distance was chosen, conservatively, based on previous studies showing that detection falls off rapidly after about $700 \mathrm{~m}$ (Heide-Jørgensen et al. 1993, 2016, Heide-Jørgensen \& Reeves 1996, Harwood et al. 1996, Harwood \& Kingsley 2013).
The FJORD and OPEN OCEAN strata were flown using distance sampling line transects (Fig. 2). The line transects for FJORD included coverage of all the main fjords on the west coast of the Spitsbergen (Hornsund, Van Keulenfjorden, Van Mijenfjorden, Isfjorden, Forlandsundet, Kongsfjorden and Krossfjorden) (Figs. 1 \& 2). Parallel lines, spaced $2 \mathrm{~km}$ apart (Fig. 2B), were flown from the mouth of each fjord, as far as possible into the fjord without overlapping the COAST stratum. The line transects in the OPEN OCEAN stratum were flown from the COAST stratum (outer edge) into offshore areas in a direction perpendicular to the coastline (Fig. 2C). Each OPEN OCEAN transect was composed of 2 parallel transect lines (one out and the other back in, spaced $1 \mathrm{~km}$ apart to take advantage of the return flight; Fig. 2C) at a length of $12 \mathrm{~km}$. To determine precisely where offshore transects would be placed, the entire coastline of Svalbard was projected into one dimension; the start point for the first transect was selected randomly and subsequent transects were systematically spaced $90 \mathrm{~km}$ apart (Fig. 2). Transects occurring in zones already covered by the 2 other strata were excluded.

To decrease the probability of counting the same groups of animals multiple times or missing animals during the survey, the major regions of Svalbard (northwest, northeast, southwest and southeast) and also major islands such as Nordaustlandet, Edgeøya and Barentsøya were flown consecutively (with all strata combined) within time frames that were as tight as possible. Since summer tracking data suggested that densities ranged from highest to lowest from the southeast, southwest, northwest, to the northeast region (Fig. 1), this pattern of coverage was followed. Edgeøya, Barentsøya and Nordaustlandet were flown after the Spitsbergen flights had been completed. Each time white whales were detected, a waypoint was registered on a PC using the 'Aerial Survey Registration Program', adapted specifically for this survey (V. Bakken \& F. Mehlum unpubl. data); each sighting was also recorded manually in a notebook. The position of the sightings (landside or seaside) was recorded as well. For each sighting, the number of individuals detected 


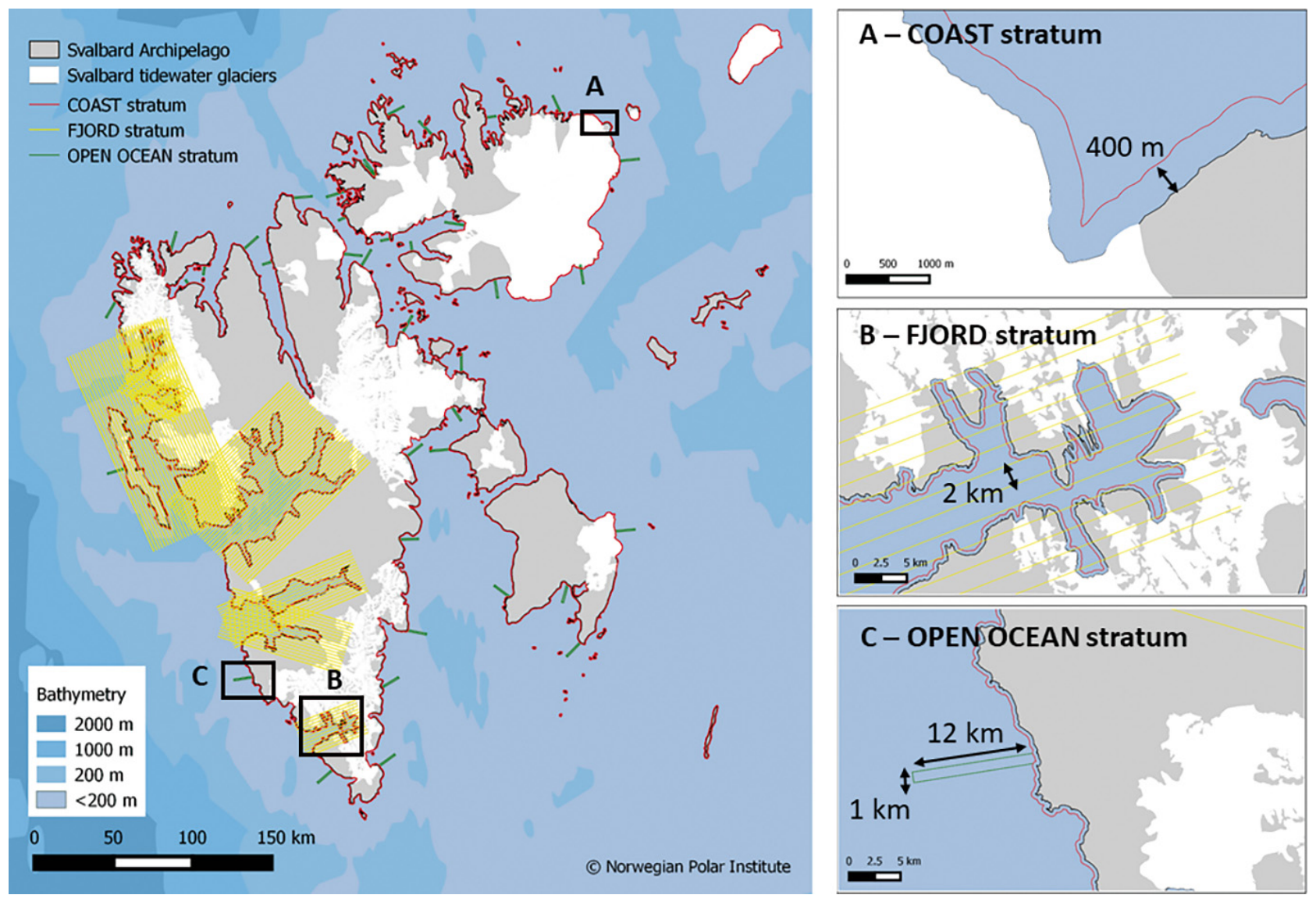

Fig. 2. Design of the aerial survey conducted to estimate the number of white whales within the Svalbard Archipelago, Norway. (A-C) Examples of the 3 strata

as well as the perpendicular distance of the whales to the track line was recorded. The latter information was calculated using the software Geometer (PI Technology) by combining the roll angle between the aircraft and the sighting and the plane's altitude. Additionally, the turbidity of the water (turbid or clear) was recorded automatically every second on the PC, with observers subjectively noting when a shift occurred (from turbid to clear or the reverse).

\subsection{Abundance estimation}

Each of the 3 different strata used as the basis for this aerial survey would normally require specific multipliers for detectability/availability to produce unbiased abundance estimates. However, since no white whales were detected in either the FJORD or the OPEN OCEAN strata (see the Section 3 for more details), only the COAST stratum methodology is described below.
In contrast to distance sampling line transects, which estimate detectability from the survey data, extrapolating numbers based on distance to the track line (e.g. Buckland et al. 2001), the total count approach used for the COAST stratum assumes total detectability, which means that detectability is not estimated. However, this refers only to detection at the surface, conditional on a group being available to be detected, and hence an availability correction factor that accounts for animals that were underwater at the time of the survey must still be used. The probability of animals being available was estimated as the mean proportion of time spent at the surface by individuals, using July-August diving data for this stock. This was estimated from behavioural records for the same 16 individuals considered in Fig. 1 ( $N=13951$ dives; J. Vacquié-Garcia, C. Lydersen \& K. M. Kovacs unpubl. data). Since white whales in Svalbard use glacier fronts extensively for foraging, diving behaviour is likely to be different in these areas. Hence, separate availability correction factors, one for glacier fronts and another for other areas, were calculated. 
The first used only the diving data from tidewater glacier fronts. The second was calculated based on diving data from all other coastal areas. A threshold of $5 \mathrm{~km}$ to a glacier front or to the coast was used to quié-Garcia et al. 2018). The turbidity of the water will also lead to different availability (Innes et al. 2002, Kingsley \& Gauthier 2002), and for this reason the 2 correction factors were calculated using 2 different surface thresholds. Thresholds of 1.5 and $3 \mathrm{~m}$ were chosen to account for surface availability in turbid and clear water, respectively. These values are somewhat shallower than those commonly used (cf. Innes et al. 2002) because even 'clear' water in this area is somewhat turbid. This is because glaciers cover more than half of Svalbard's landmass and $60 \%$ of these are tidewater glaciers, which drain an enormous amount of turbid melt water into the fjord systems of the archipelago (Lydersen et al. 2014). This resulted in the calculation of 4 different availability correction factors, corresponding to the factorial crossing of area and turbidity: (1) turbid water in front of glacier fronts, (2) clear water in front of glacier fronts, (3) turbid water outside glacier fronts, and (4) turbid water outside glacier fronts. These 4 availability correction factor estimates were then used separately to scale up the counts of the individuals detected to obtain 4 different availability corrected abundance estimates (N1, N2, N3 and N4; Fig. 3A), which were then summed to obtain the overall availability corrected abundance estimate (Overall Ni Fig. 3B). Finally, the overall availability corrected abundance estimate was distinguish between these areas (see details in Vac-

divided by the proportion of the covered area (a simple design-based approach) to take into account the small area of COAST stratum that was not covered by flights (due mainly to bad weather; see Fig. 3) to obtain the final estimate (Final N; Fig. 3C).

To account for the dependence structure induced in the different correction factors due to the same tagged individuals being used in different areas, variance was estimated via a common bootstrap procedure, resampling individual tags (i.e. considering 16 independent sampling units). The same procedure described previously was repeated, and the variance around the abundance estimate $(\mathrm{CI}=95 \%)$ was directly obtained from this bootstrap exercise. The variance component induced in the correction factor for the small proportion of coastal areas that were not covered was ignored (see Section 4 for rationale).

\section{RESULTS}

The aerial survey was flown between 29 July and 17 August 2018 and included 11 actual flying days (Fig. 4). Zones 1, 2, 3 and 4 in Fig. 4, corresponding to the southern and western parts of Spitsbergen, were covered in a $7 \mathrm{~d}$ period ( $6 \mathrm{~d}$ with flights). Zones 5, 6 and 7, corresponding to the north and the eastern part of Spitsbergen, were covered in the following $4 \mathrm{~d}$ (3 d with flights) and the north and eastern parts of Nordaustlandet, corresponding to zones 8 and 9, were flown during $2 \mathrm{~d}$, spread across the 9 last days of the survey period.

A total of $4965 \mathrm{~km}$ of survey cover-

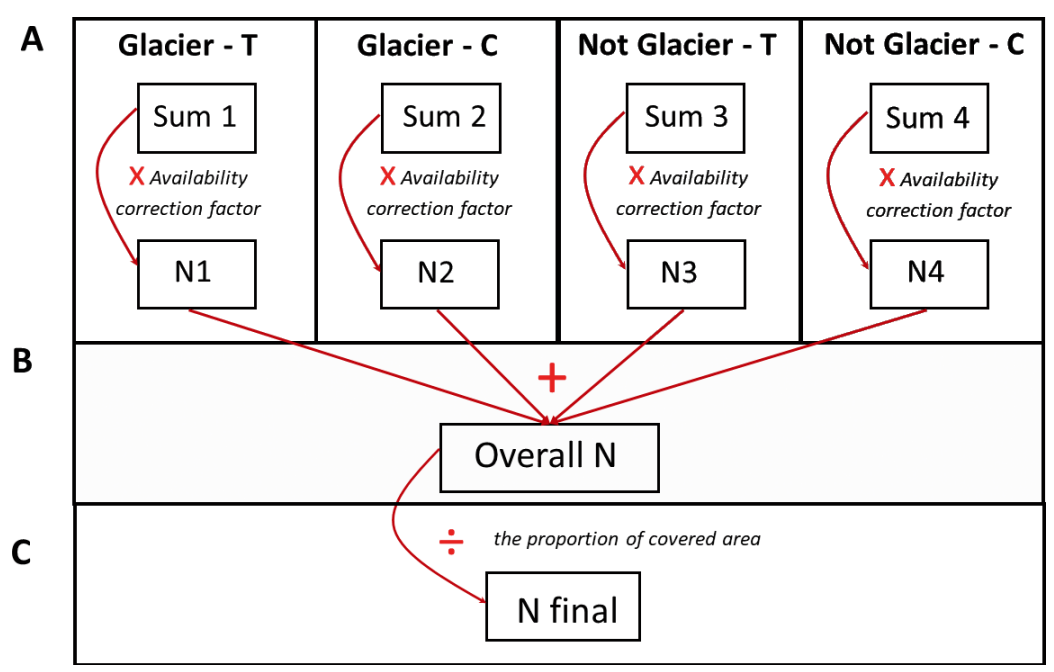

Fig. 3. (A-C) Steps involved in white whale abundance $(N)$ estimation methodology. Glacier-T, Glacier-C, Not Glacier-T and Not Glacier-C represent the factorial crossing of area and turbidity: in front of glacier fronts in turbid and clear water, and outside glacier fronts in turbid and clear water, respectively age were flown in the COAST stratum, $1481 \mathrm{~km}$ in the FJORD stratum (55 line transects) and $535 \mathrm{~km}$ in the OPEN OCEAN stratum (55 line transects; Fig. 5). Most of the planned lines were flown. Exceptions occurred for a few small areas along the COAST $(94.3 \%$ covered) and several of the planned OPEN OCEAN transects $(70.6 \%$ covered) in the north of Spitsbergen and Nordaustlandet; additionally, a few small islands were missed due to bad weather (Figs. $2 \& 5$ ).

A total of 22 white whale sightings involving 265 individuals were recorded in the COAST stratum (Table 1, Fig. 5). No whales were detected in either the FJORD or the OPEN OCEAN strata (Fig. 5). Most sightings occurred in the southern and northwestern parts 


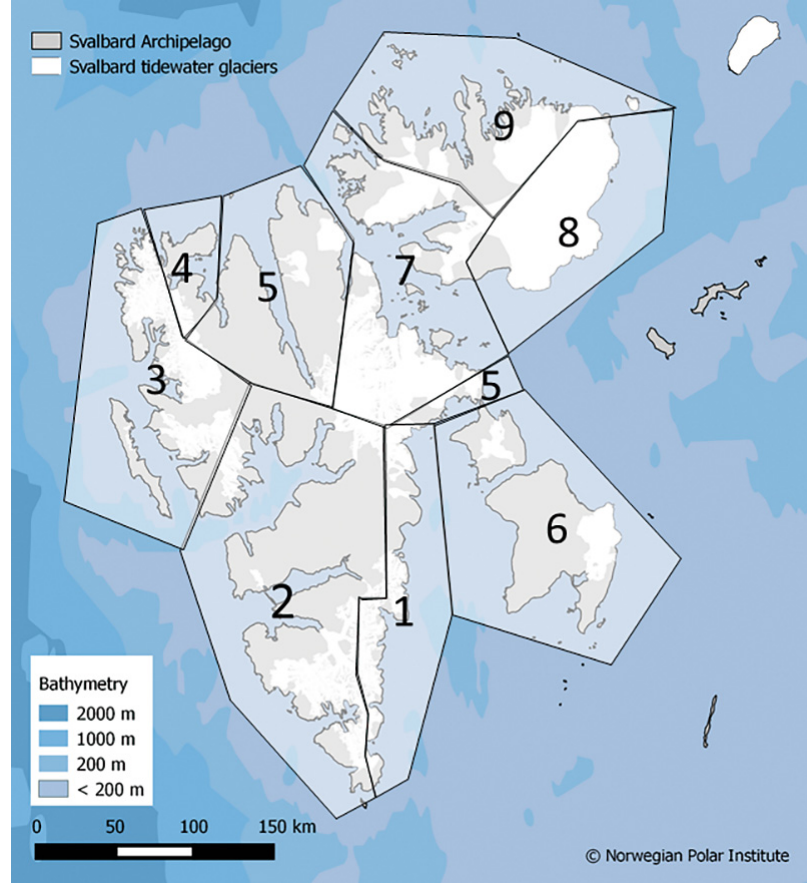

Fig. 4. Timing of the aerial survey conducted to estimate the number of white whales within the Svalbard Archipelago, Norway. Areas 1, 2 and 3 were flown on 29 and 30/31 July and 2/3 August, respectively. Areas 4, 5 and 6 were flown on 4, 5 and 6 August. Areas 7, 8 and 9 were flown on 8, 13 and 17 August, respectively. Gaps between flying periods were due to bad weather

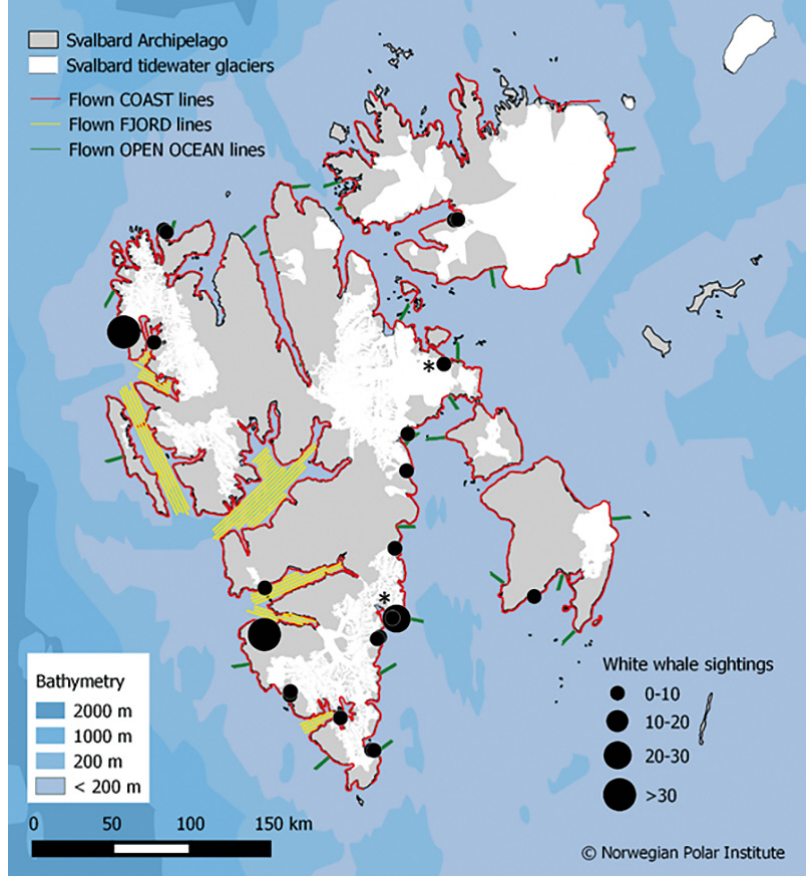

Fig. 5. Locations of white whale sightings during aerial survey of the Svalbard Archipelago, Norway, summer 2018. All sightings occurred within the COAST stratum (see Fig. 2). $\left({ }^{*}\right)$ mother-calf pair sightings

Table 1. White whale sightings during an aerial survey conducted in the Svalbard Archipelago, summer 2018. Characteristics include location of sightings along transect lines as well as estimated distance of detection (i.e. distance to line transects) and group size. Water conditions ( $\mathrm{T}$ : turbid; C: clear) and calculated distance to the coast and to tidewater glacier fronts are also included

\begin{tabular}{|c|c|c|c|c|c|c|c|c|c|}
\hline Date, time & $\begin{array}{l}\text { Longitude } \\
\left({ }^{\circ} \mathrm{E}\right)\end{array}$ & $\begin{array}{c}\text { Latitude } \\
\left({ }^{\circ} \mathrm{N}\right)\end{array}$ & Location & Strata & Water & $\begin{array}{l}\text { Group } \\
\text { size }\end{array}$ & $\begin{array}{c}\text { Distance of } \\
\text { detection }(\mathrm{m})\end{array}$ & $\begin{array}{l}\text { Distance to } \\
\text { the coast }(\mathrm{m})\end{array}$ & $\begin{array}{c}\text { Distance to } \\
\text { glacier front }(\mathrm{m})\end{array}$ \\
\hline $29 \mathrm{Jul}, 17: 50 \mathrm{~h}$ & 19.09 & 78.54 & Landside & $\mathrm{C}$ & $\mathrm{T}$ & 3 & 997.61 & 0 & 0 \\
\hline $29 \mathrm{Jul}, 18: 08 \mathrm{~h}$ & 18.89 & 78.33 & Landside & $\mathrm{C}$ & $\mathrm{C}$ & 9 & 598.60 & 0 & 255.70 \\
\hline 29 Jul, 18:41 h & 18.26 & 77.90 & Landside & $\mathrm{C}$ & $\mathrm{T}$ & 4 & 312.39 & 388.23 & 2538.89 \\
\hline 29 Jul, 19:15 h & 18.04 & 77.50 & Landside & $\mathrm{C}$ & $\mathrm{T}$ & 28 & 265.13 & 216.85 & 4891.67 \\
\hline $29 \mathrm{Jul}, 19: 16 \mathrm{~h}$ & 17.93 & 77.51 & Seaside & $\mathrm{C}$ & $\mathrm{T}$ & 5 & 305.00 & 830.86 & 3755.93 \\
\hline $29 \mathrm{Jul}, 19: 27 \mathrm{~h}$ & 17.53 & 77.41 & Seaside & $\mathrm{C}$ & $\mathrm{T}$ & 2 & 305.00 & 796.85 & 3529.96 \\
\hline $29 \mathrm{Jul}, 19: 27 \mathrm{~h}$ & 17.47 & 77.40 & Landside & $\mathrm{C}$ & $\mathrm{T}$ & 7 & 162.17 & 292.47 & 1494.92 \\
\hline $29 \mathrm{Jul}, 20: 09 \mathrm{~h}$ & 16.97 & 76.77 & Seaside & $\mathrm{C}$ & $\mathrm{T}$ & 1 & 221.60 & 687.73 & 2394.53 \\
\hline $29 \mathrm{Jul}, 20: 10 \mathrm{~h}$ & 17.03 & 76.77 & Seaside & $\mathrm{C}$ & $\mathrm{T}$ & 1 & 327.07 & 841.47 & 3623.00 \\
\hline $30 \mathrm{Jul}, 14: 31 \mathrm{~h}$ & 16.29 & 76.98 & Landside & $\mathrm{C}$ & $\mathrm{C}$ & 8 & 315.84 & 0 & 1527.46 \\
\hline $30 \mathrm{Jul}, 15: 44 \mathrm{~h}$ & 15.08 & 77.14 & Landside & $\mathrm{C}$ & $\mathrm{C}$ & 5 & 390.38 & 0 & 1641.67 \\
\hline $30 \mathrm{Jul}, 15: 45 \mathrm{~h}$ & 15.10 & 77.16 & Seaside & $\mathrm{C}$ & $\mathrm{C}$ & 2 & 284.42 & 686.64 & 686.64 \\
\hline $30 \mathrm{Jul}, 16: 25 \mathrm{~h}$ & 14.55 & 77.49 & Landside & $\mathrm{C}$ & $\mathrm{C}$ & 55 & 221.60 & 341.92 & 4031.90 \\
\hline 31 Jul, 09:26 h & 14.66 & 77.76 & Landside & $\mathrm{C}$ & $\mathrm{T}$ & 6 & 274.62 & 49.89 & 2825.84 \\
\hline 2 Aug, 15:26 h & 11.92 & 79.20 & Landside & $\mathrm{C}$ & $\mathrm{C}$ & 8 & 89.03 & 456.63 & 7046.82 \\
\hline 2 Aug, 16:31 h & 11.00 & 79.27 & Landside & $\mathrm{C}$ & $\mathrm{C}$ & 100 & 0 & 368.60 & 4494.45 \\
\hline 4 Aug, $12: 18 \mathrm{~h}$ & 12.35 & 79.84 & Seaside & $\mathrm{C}$ & $\mathrm{C}$ & 1 & 452.18 & 1180.63 & 12330.69 \\
\hline 4 Aug, $12: 19 \mathrm{~h}$ & 12.43 & 79.83 & Seaside & $\mathrm{C}$ & $\mathrm{C}$ & 1 & 718.53 & 1330.99 & 12991.90 \\
\hline 6 Aug, $17: 19$ h & 21.69 & 77.49 & Landside & $\mathrm{C}$ & $\mathrm{T}$ & 7 & 1138.28 & 0 & 32264.36 \\
\hline 8 Aug, 10:45 h & 20.47 & 78.90 & Seaside & $\mathrm{C}$ & $\mathrm{T}$ & 2 & 625.34 & 1084.36 & 1084.36 \\
\hline 8 Aug, 16:06 h & 21.62 & 79.70 & Seaside & $\mathrm{C}$ & $\mathrm{T}$ & 9 & 284.42 & 846.93 & 846.93 \\
\hline 8 Aug, 16:07 h & 21.74 & 79.70 & Landside & $\mathrm{C}$ & $\mathrm{T}$ & 1 & 205.73 & 259.17 & 259.17 \\
\hline
\end{tabular}


of Spitsbergen (Fig. 5). Two sightings occurred along the Nordaustlandet coastline (Fig. 5). The mean $( \pm \mathrm{SE})$ group size was $12 \pm 5$ ind. sighting $^{-1}$ (range: 1-100) (Table 1).

The mean distance from the sightings to the track line was estimated to be $386 \pm 59 \mathrm{~m}$. (Table 1, Fig. 6). A total of 13 sightings were made on the landside and 9 were on the seaside of the aircraft (Table 1 , Fig. 6). Among the 9 sightings on the seaside, 3 were recorded at distances greater than $400 \mathrm{~m}$ to the track line (max. $718 \mathrm{~m}$; Table 1, Fig. 6). Among the 13 sightings on the landside, 3 occurred at distances greater than $400 \mathrm{~m}$ to the track line (max. $1138 \mathrm{~m}$; Table 1, Fig. 6). In a strip survey context, where the number of detections is divided by the area covered, sightings occurring at distances beyond $400 \mathrm{~m}$ to the track line should be removed from analyses. However, in a total count like the one performed herein for the COAST stratum, all sightings need to be included, under the assumption of total detectability. In that case, the rarity of 'far' sightings could be interpreted as being a decrease in detectability with increasing distance from the track line, which would contradict the assumption of total detectability. However, this is unlikely to be the case in this survey. The landside sightings that were $>400 \mathrm{~m}$ occurred at the bottom of small, shallow bays that were crossed by the aircraft at their mouths (for safety reasons). The frequency of such situations was rare enough to explain the low number of sightings detected above the threshold, and full visibility into these bays, whatever the distance of detection, was likely achieved. The few distant sightings on the seaside of the aircraft likely reflect a real decrease in density away from the shoreline. This is supported by the fact that $700 \mathrm{~m}$ from the track line is considered to be acceptable for the detection of white whales by other studies in open water (Heide-Jørgensen et al. 1993, 2016, HeideJørgensen \& Reeves 1996, Harwood et al. 1996, Harwood \& Kingsley 2013). In this context, the inclusion of the few sightings ( 3 on each side) in the total count of the COAST stratum was considered to be acceptable, and all the sightings done along the COAST stratum were used to estimate abundance.

In total, 18 of the 22 sightings ( $82 \%$ ) occurred in areas classified as glacier fronts; 6 of these were in clear water while the other 12 were in turbid water (Table 1). The estimated percentage of time available for detection at the surface for white whales in glacier front areas was $41 \pm 6$ and $56 \pm 8 \%$ for turbid and clear water, respectively. Only 4 sightings occurred outside glacier front areas and of these, 3 occurred in clear water while the other one was in turbid water

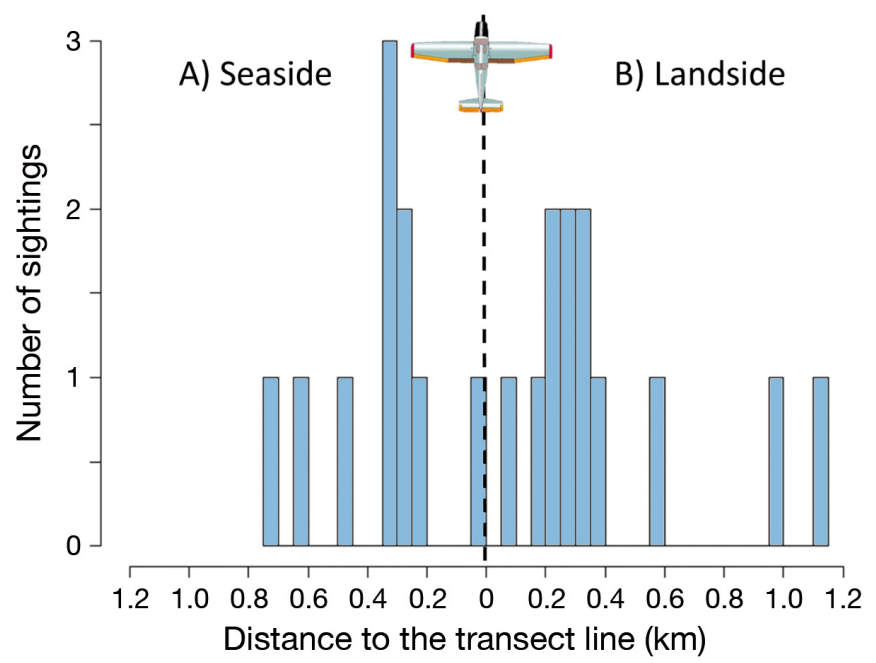

Fig. 6. Distance between the plane and sighting locations of white whales during an aerial survey conducted in the Svalbard Archipelago, summer 2018

(Table 1). The estimated percentage of time available for detection at the surface in these (non-glacier front) areas was $48 \pm 6$ and $64 \pm 6 \%$ for turbid and clear water, respectively. After the availability correction factors were applied to the corresponding counts, and after the correction for uncovered areas was made, the estimated number of white whales in Svalbard was determined to be 549 individuals (95\% CI: 436-723).

\section{DISCUSSION}

This study provides the first abundance estimate for white whales in the Svalbard Archipelago. White whales in Svalbard generally exhibit extremely coastal movement patterns, and this behaviour, combined with recent observations and tracking results showing that they have started using central areas in some fjords (Lydersen et al. 2001, Vacquié-Garcia et al. 2018), created some challenges regarding the survey design. This was addressed by creating 3 different strata based on tracking studies conducted at the same time of year in the same area. The largest drawback of the design employed here was the large distance between independent transect lines in the OPEN OCEAN (i.e. $90 \mathrm{~km}$ ), making it possible that some groups of animals might have been missed. This distance was chosen based on logistic constraints, as a trade-off between enough OPEN OCEAN coverage and the short total study period, to avoid significant movement of individual animals between areas during the survey, which would raise concerns regarding double counting and/or missing animals. 
The risk of missing groups of animals or counting some groups multiple times is particularly problematic for small stocks in restricted areas, when highly mobile animals are the survey target species. The repercussions of missing or double counting groups are accentuated when the group is large (for instance 100 individuals, which occurred in the observations in this study). However, in this survey, the distance from the aircraft to the coastline along the COAST stratum was short (400 $\mathrm{m}$ to the coast), minimizing the risk of missing animals, especially large groups. Additionally, although the survey was conducted over a $20 \mathrm{~d}$ period (with 11 flying days), tracking data show that white whales spend most of their time in the southern and western parts of Spitsbergen during the summer, and the coastlines, fjords and offshores areas in these zones were all surveyed in consecutive flights during a short interval (less than $7 \mathrm{~d}$ ). Thus, it is unlikely that large groups were missed or that double counting of groups occurred in the COAST stratum.

During the survey, all sightings occurred in the COAST stratum. This result is consistent with the coastal behaviour of white whales in Svalbard, which has been documented in tracking studies as well as in the marine mammal sighting database run by the Norwegian Polar Institute (NPI) (Lydersen et al. 2001, Storrie et al. 2018, Vacquié-Garcia et al. 2018). In addition, most sightings of white whales during this survey occurred close to glacier fronts (Table 1). This is also consistent with results from previous tracking studies, which have repeatedly shown that the whales spend a lot of time in these specific areas in Svalbard, moving between tidewater glacier fronts in a rapid and directed manner, travelling close to the coast (Lydersen et al. 2001, Vacquié-Garcia et al. 2018). However, in the most recent tracking studies, the white whales in Svalbard have apparently been spending more time in areas corresponding to the FJORD and OPEN OCEAN strata (respectively 21.5 and $46.7 \%$ of the tracking data in those strata compared to $31.4 \%$ in the COAST stratum; Vacquié-Garcia et al. 2018, Hamilton et al. 2019). No sightings of white whales occurred in these strata during the survey. This was somewhat surprising, but the fact that white whale were not seen in the OPEN OCEAN or in the FJORD strata was reassuring regarding the design of the survey. The most probable explanation of that result is that time spent outside the COAST stratum, based on tracking data, might have been overestimated by previous studies. This would happen as a consequence of Argos error classifying locations as being in FJORD or OPEN OCEAN strata when in reality the real locations correspond to animals actually occurring within the COAST stratum.

Other potential biases arising from using the tracking data to inform the survey design are that tagging location could bias movement patterns and that sex might be influential. All of the 34 white whales whose tracking has been reported in the literature were males that were caught in shore-set nets along the coastline of Spitsbergen. None of these animals moved significant distances offshore during the summer months, which was the basis of this survey. If an offshore 'ecotype' did exist in this region, or if females behave differently than males in terms of use of offshore areas, the survey could potentially underestimate the stock size. However, no animals were sighted on any of the offshore lines during the survey, and significant offshore effort by various research programmes and tour operators well beyond the $12 \mathrm{~km}$ limit used in this survey consistently report to the NPI Sighting Database a lack of white whales offshore (see Storrie et al. 2018). Thus, it is unlikely that longer offshore lines would have resulted in a significantly larger number of sightings during the survey effort. Nonetheless, when this survey is repeated, more effort should take place in the offshore strata, to ensure that animals are not being missed. In the present survey, 2 sightings of white whales occurred along the coast of Nordaustlandet (Figs. 1 \& 5), despite the fact that tracked animals have never travelled this far to the northeast within Svalbard. The 2 sightings in this area were included in the Svalbard stock assessment because the distance between Spitsbergen and Nordaustlandet is short, and the Hinlopen Strait could be traversed easily by white whales. However, establishing whether these animals are part of another stock, perhaps distributed eastwards towards the Russian Archipelago of Frans Josef Land, should be investigated.

The sightings of white whales in the present survey within the COAST stratum occurred mainly on the landside of the airplane, which is consistent with their tightly coastal movement patterns (Lydersen et al. 2001, Vacquié-Garcia et al. 2018). Most of the sightings (on both sides of the plane) were at distances of less than $400 \mathrm{~m}$ from the track line, which was the distance the aircraft flew out from the coast. However, few sightings were actually on or close to the track line, despite good visibility on the line afforded by the bubble window in the front of the aircraft. This is likely a random effect, given the small total number of sightings recorded in the present study. It is also important to note that some sightings occurred at distances greater than $400 \mathrm{~m}$ from the 
track line, with a maximum distance of $1138 \mathrm{~m}$. As noted in the Section 3, these distant sightings were included in the abundance estimate, based on a total count approach being attempted.

The abundance estimation along the COAST stratum involved the application of availability correction factors and correction factors for uncovered areas. It is important to note as well that this survey was a single observer design, which means that the observer team as a whole could miss animals (i.e. perception bias) and if this occurred, the estimate obtained would be negatively biased. However, the perception bias is likely to be small given the short distances over which observations took place; thus, it was ignored in this study. The availability correction factors used in the present study to correct the sightings for the amount of time white whales spend on the surface in various environments are relatively high (ranging from 41-64\%). This is likely due to the highly coastal nature of white whales in Svalbard, which results in shallower dives and more time at the surface being the norm. For areas not covered by the COAST stratum survey effort, the numbers of animals that were potentially missed were simply extrapolated based on covered areas. This simple solution assumes that areas were missed at random and that animals are spread evenly through the whole stratum. This is known not to be the case, since glacier fronts represent a high-density environment compared to the rest of the coast. A model-based approach, with a spatial model including distance to glacier fronts along with other relevant covariates to describe density along the coast could be applied to make this correction more realistic. However, given the low proportion of the total coastal stratum not covered $(5.7 \%)$, and the mix of glacier front versus non-glacier front in the missed areas, such a spatial model would most likely induce negligible changes in the estimate. It is also worth noting that the additional variance component introduced by this extrapolation procedure was not incorporated because (1) it is not straightforward to obtain a measure of this variance (given untestable assumptions about the sampling process), and (2) the fraction of the overall variability (with $94.3 \%$ of the survey area covered) would have very little influence on the overall variance and confidence intervals.

After correction factors were applied for availability at the surface according to turbidity conditions and for uncovered areas, the abundance of white whales in Svalbard was estimated to be 549 (95\% CI: 436-723) animals. Even considering the possibility that a small fraction of the animals might have been missed (e.g. a missed group in the OPEN OCEAN strata), this estimate suggests that the Svalbard stock is one of the smallest white whale stocks in the world. This small number is somewhat surprising given that white whales are one of the most commonly observed cetaceans in the Svalbard area (NPI Marine Mammal Sighting Database; Storrie et al. 2018). However, these whales are relatively easy to spot because they are white, they often occur in groups and travel very close to the coast. In addition, they spend much of their time in the summer months on the west coast where most people in the archipelago live and where tourism activities are most concentrated. These factors may create a false impression of a higher abundance of white whales in this area. When spotting for white whales in other areas of Svalbard during field work directed towards capturing white whales for tracking studies, the authors searched for more than 1 mo, repeatedly, without observing any white whales (K. M. Kovacs \& C. Lydersen unpubl. data).

Since this is the first abundance estimate for this stock, there is obviously no previous comparative data. However, by the start of the 1960s the stock was thought to be so small that it was considered 'economically extinct' (Lønø \& Øynes 1961). There is no doubt that the Svalbard white whales were seriously overexploited before protection was put in place some $50 \mathrm{yr}$ ago. The extreme reduction of this population likely created significant social disruption (Wade et al. 2012) and also potentially loss of knowledge of formerly occupied areas (Colbeck et al. 2013), which might play a role in their current habitat occupancy and restricted movement patterns. Whether or not the stock is recovering post-protection is impossible to know with certainty, but animals appear to be in good condition, and observations around the archipelago include significant numbers of calves, which is reassuring (K. M. Kovacs \& C. Lydersen unpubl. data), although few calves were documented by the survey effort (Fig. 5).

Marked declines in sea ice in Svalbard (Laidre et al. 2015) are a concern for white whale recovery, as well as for the well-being of other ice-associated marine mammals in the region (Kovacs et al. 2011, Hamilton et al. 2015, 2016, 2017, 2019), although white whales seem to be making some adaptive responses to deal with the changes that are taking place in the archipelago (Vacquié-Garcia et al. 2018, Hamilton et al. 2019). Other risks associated with global warming include increased risk of diseases in a warmer climate, increased competition from temperate species that are expanding northward, in- 
creased prevalence of shipping and development in the north (in particular from the oil and gas industry) and the potential for increased effects of pollution (e.g. Harvell et al. 1999, Macdonald et al. 2005, Burek et al. 2008, Moore \& Huntington 2008, Noyes et al. 2009, Van Bressem et al. 2009, Jensen et al. 2010, Letcher et al. 2010, Reeves et al. 2014). Increased predation pressure from common predators of white whales, specifically polar bears Ursus maritimus and killer whales Orcinus orca, is also expected as a consequence of the predicted decline of the availability of seals (see Karlsen et al. 2002 and Vacquié-Garcia et al. 2018 for more details).

In conclusion, this study provides the first abundance estimate for white whales in the Svalbard Archipelago. The low estimate for this region is cause for concern, particularly given on-going climate warming and other threats that could slow the recovery of the stock. Genetics studies should be conducted as soon as possible to ascertain the complete population structure of white whales in the Barents Region, and Svalbard should be surveyed again as quickly as possible. Multiple observation platforms should be used in future surveys in order to shorten the survey duration and increase the area covered. In the meantime, a conservative management regime should be put in place, affording additional protection to key habitat areas, especially those used by mothers and calves.

Acknowledgements. This study was supported by funds from the Norwegian Polar Institute, the Norwegian Research Council (ICE-WHALES, TIGRIF and GLAERE programmes), the Norwegian Polar Institute's ICE Centre and the Fram Centre's Fjord and Coast Flagship. T.A.M. was partially supported by CEAUL (funded by FCT - Fundação para a Ciência e a Tecnologia, Portugal, through the project UID/MAT/00006/2019). We thank Samuel Martínez Llobet and Ricky Lindy Nielsen (Bioflight) for help in the field.

\section{LITERATURE CITED}

Berge J, Heggland K, Lønne OJ, Cottier F and others (2015) First records of Atlantic mackerel (Scomber scombrus) from the Svalbard Archipelago, Norway, with possible explanations for the extension of its distribution. Arctic 68:54-61

Buckland ST, Anderson DR, Burnham KP, Laake JL, Borchers DL, Thomas L (2001) Introduction to distance sampling. Oxford University Press, Oxford

Burek KA, Gulland FM, O'Hara TM (2008) Effects of climate change on Arctic marine mammal health. Ecol Appl 18: S126-S134

Colbeck GJ, Duchesne P, Postma LD, Lesage V, Hammill MO, Turgeon J (2013) Groups of related belugas (Delphinapterus leucas) travel together during their seasonal migrations in and around Hudson Bay. Proc R Soc B 280: 20122552

* Cottier FR, Nilsen F, Inal ME, Gerland S, Tverberg V, Svendsen H (2007) Wintertime warming of an Arctic shelf in response to large-scale atmospheric circulation. Geophys Res Lett 34:L10607

* Dahl TM, Lydersen C, Kovacs KM, Falk-Petersen S, Sargent J, Gjertz I, Gulliksen B (2000) Fatty acid composition of the blubber in white whales (Delphinapterus leucas). Polar Biol 23:401-409

Doniol-Valcroze T, Hammill MO (2012) Information on abundance and harvest of Ungava Bay beluga. Can Sci Advis Sec Res Doc 2011/126

Gjertz I, Wiig O (1994) Distribution and catch of white whales (Delphinapterus leucas) at Svalbard. Medd Gronl Biosci 39:93-97

*Hamilton CD, Lydersen C, Ims RA, Kovacs KM (2015) Predictions replaced by facts: a keystone species' behavioural responses to declining Arctic sea-ice. Biol Lett 11: 20150803

Hamilton CD, Lydersen C, Ims RA, Kovacs KM (2016) Coastal habitat use by ringed seals Pusa hispida following a regional sea-ice collapse: importance of glacial refugia in a changing Arctic. Mar Ecol Prog Ser 545: 261-277

*Hamilton CD, Kovacs KM, Ims RA, Aars J, Lydersen C (2017) An Arctic predator-prey system in flux: climate change impacts on coastal space use by polar bears and ringed seals. J Anim Ecol 86:1054-1064

*Hamilton CD, Vacquié-Garcia J, Kovacs KM, Ims RA, Kohler J, Lydersen C (2019) Contrasting changes in space use induced by climate change in two Arctic marine mammal species. Biol Lett 15:20180834

*Harvell CD, Kim K, Burkholder JM, Colwell RR and others (1999) Emerging marine diseases - climate links and anthropogenic factors. Science 285:1505-1510

Harwood LA, Kingsley MCS (2013) Trends in the offshore distribution and relative abundance of Beaufort Sea belugas, $1982-85$ vs 2007-09. Arctic 66:247-256

* Harwood LA, Innes S, Norton P, Kingsley MC (1996) Distribution and abundance of beluga whales in the Mackenzie estuary, southeast Beaufort Sea, and West Amundsen Gulf during late July 1992. Can J Fish Aquat Sci 53: 2262-2273

*Heide-Jørgensen MP, Laidre KL (2004) Declining extent of open-water refugia for top predators in Baffin Bay and adjacent waters. Ambio 33:487-494

*Heide-Jørgensen MP, Reeves R (1996) Evidence of a decline in beluga, Delphinapterus leucas, abundance off West Greenland. ICES J Mar Sci 53:61-72

*Heide-Jørgensen MP, Lassen H, Teilmann J, Davis RA (1993) An index of the relative abundance of wintering belugas, Delphinapterus leucas, and narwhals, Monodon monoceros, off West Greenland. Can J Fish Aquat Sci 50: 2323-2335

*Heide-Jørgensen MP, Sinding MHS, Nielsen NH, RosingAsvid A, Hansen RG (2016) Large numbers of marine mammals winter in the North Water Polynya. Polar Biol 39:1605-1614

* Innes S, Heide-Jørgensen MP, Laake JL, Laidre KL, Cleator HJ, Richard P, Stewart REA (2002) Surveys of belugas and narwhals in the Canadian High Arctic in 1996. NAMMCO Sci Publ 4:169-190

Jensen SK, Aars J, Lydersen C, Kovacs KM, Åsbakk K (2010) The prevalence of Toxoplasma gondii in polar bears and 
their marine mammal prey: Evidence for a marine transmission pathway? Polar Biol 33:599-606

Karlsen JD, Bisther A, Lydersen C, Haug T, Kovacs KM (2002) Summer vocalisations of adult male white whales (Delphinapterus leucas) in Svalbard, Norway. Polar Biol 25:808-817

Kingsley MCS, Gauthier I (2002) Visibility of St. Lawrence belugas to aerial photography estimated by direct observation. NAMMCO Sci Publ 4:259-270

Kovacs KM, Moore S, Overland JE, Lydersen C (2011) Impacts of changing sea ice conditions on Arctic marine mammals. Mar Biodivers 41:181-194

Laidre KL, Stern H, Kovacs KM, Lowry L and others (2015) Arctic marine mammal population status, sea ice habitat loss, and conservation recommendations for the 21st century. Conserv Biol 29:724-737

Letcher RJ, Bustnes JO, Dietz R, Jenssen BM and others (2010) Exposure and effects assessment of persistent organohalogen contaminants in Arctic wildlife and fish. Sci Total Environ 408:2995-3043

Lønø O, Øynes P (1961) White whale fishery at Spitsbergen. Nor Hvalfangst-Tid 50:267-287

Lowry L, Reeves R, Laidre K (2017) Delphinapterus leucas. The IUCN Red List of Threatened Species 2017:e.T6335 A50352346

Lydersen C, Martin AR, Kovacs KM, Gjertz I (2001) Summer and autumn movements of white whales Delphinapterus leucas in Svalbard, Norway. Mar Ecol Prog Ser 219: 265-274

Lydersen C, Nøst OA, Lovell P, McConnell BJ and others (2002) Salinity and temperature structure of a freezing Arctic fjord-monitored by white whales (Delphinapterus leucas). Geophys Res Lett 29:2119

Lydersen C, Assmy P, Falk-Petersen S, Kohler J and others (2014) The importance of tidewater glaciers for marine mammals and seabirds in Svalbard, Norway. J Mar Syst 129:452-471

Macdonald RW, Harner T, Fyfe J (2005) Recent climate change in the Arctic and its impact on contaminant pathways and interpretation of temporal trend data. Sci Total Environ 342:5-86

Matthews CJD, Watt CA, Asselin NC, Dunn JB and others (2017) Estimated abundance of the Western Hudson Bay beluga stock from the 2015 visual and photographic aerial survey. Can Sci Advis Sec Res Doc 2017/061

Moholdt G, Hagen JO, Eiken T, Schuler TV (2010) Geometric changes and mass balance of the Austfonna ice cap, Svalbard. Cryosphere 4:21-34

Moore SE, Huntington HP (2008) Arctic marine mammals and climate change: impacts and resilience. Ecol Appl 18:S157-S165

Editorial responsibility: Sascha Hooker,

St. Andrews, UK
Muto MM, Helker VT, Angliss RP, Allen BA and others (2016) Alaska marine mammal stock assessments, 2015. NOAA Tech Memo NMFS-AFSC-323

Noyes PD, McElwee MK, Miller HD, Clark BW and others (2009) The toxicology of climate change: environmental contaminants in a warming world. Environ Int 35:971-986

*Nuth C, Moholdt G, Kohler J, Hagen JO, Kääb A (2010) Svalbard glacier elevation changes and contribution to sea level rise. J Geophys Res 115:F01008

* O'Corry-Crowe GM, Lydersen C, Heide-Jørgensen MP, Hansen L, Mukhametov LM, Dove O, Kovacs KM (2010) Population genetic structure and evolutionary history of North Atlantic beluga whales (Delphinapterus leucas) from West Greenland, Svalbard and the White Sea. Polar Biol 33:1179-1194

* Reeves RR, Ewins PJ, Agbayani S, Heide-Jørgensen MP and others (2014) Distribution of endemic cetaceans in relation to hydrocarbon development and commercial shipping in a warming Arctic. Mar Policy 44:375-389

Shelden KEW, Sims CL, Vate Brattström L, Goetz KT, Hobbs RC (2015) Aerial surveys of beluga whales (Delphinapterus leucas) in Cook Inlet, Alaska, June 2014. AFSC Processed Report 2015-03. Alaska Fisheries Science Center, Seattle, WA

Spielhagen RF, Werner K, Sørensen SA, Zamelczyk K and others (2011) Enhanced modern heat transfer to the Arctic by warm Atlantic water. Science 331:450-453

* Stirling I (1997) The importance of polynyas, ice edges, and leads to marine mammals and birds. J Mar Syst 10:9-21

* Storrie L, Lydersen C, Andersen M, Wynn RB, Kovacs KM (2018) Determining the species assemblage and habitat use of cetaceans in the Svalbard archipelago, based on recorded observations from 2002-2014. Polar Res 37: 1463065

Stroeve J, Holland MM, Meier W, Scambos T, Serreze M (2007) Arctic Sea ice decline: faster than forecast. Geophys Res Lett 34:L09501

*Torsvik T, Albretsen J, Sundfjord A, Kohler J and others (2019) Impact of tidewater glacier retreat on the fjord system: modelling present and future circulation in Kongsfjorden, Svalbard. Estuar Coast Shelf Sci 220:152-165

*Vacquié-Garcia J, Lydersen C, Ims RA, Kovacs KM (2018) Habitats and movement patterns of white whales Delphinapterus leucas in Svalbard, Norway. Mov Ecol 6:21

* Van Bressem MF, Raga JA, Di Guardo G, Jepson PD and others (2009) Emerging infectious diseases in cetaceans worldwide and the possible role of environmental stressors. Dis Aquat Org 86:143-157

*Wade PR, Reeves RR, Mesnick SL (2012) Social and behavioural factors in cetacean responses to overexploitation: Are odontocetes less 'resilient' than mysticetes? J Mar Biol 2012:567276

Submitted: May 28, 2019; Accepted: November 26, 2019 Proofs received from author(s): February 13, 2020 